\title{
Review
}

\section{Capitalism and democracy in the twenty-first century: A global future beyond nationalism}

\author{
Gavin Kitching \\ Routledge, New York, 2020, 138 pp, ISBN: 978-0-367-35493-0
}

Contemporary Political Theory (2021) 20, S115-S118. https://doi.org/10.1057/s41296020-00413-5; published online 16 June 2020

Gavin Kitching is an unusual scholar, even in this day of incessantly vaunted 'interdisciplinarity' and 'cross-disciplinarity', for he is an accomplished anthropologist, Africanist, philosopher, historian, and economist-not to mention political theorist/scientist and sociologist. And as he discloses in chapter one of this book, he has 72 years of life experience to call upon. All of this is edifyingly on show in his short book on the prospects of democracy, democratic participation, and democratic legitimacy in the coming decades of the twenty-first century. The book sets out an illuminating and compelling analysis of the current state and developmental trajectory of our shared economic and political form of life. Intrinsic to this analysis is an outline of its possible further developmental trajectories in the near to medium term and an impassioned case for working to realise those possibilities that he argues would secure a humane future for all of the planet's citizens.

Kitching's personal voice is prominent throughout his writing: he writes engagingly in the first person. His book seeks both to describe, analytically, the essential structure of contemporary capitalism which now rules globally, just as Marx foresaw it would, and to be an advocate for possible future developments of it that would render it fit for delivering a 'a feasible socialism' (p.124). Kitching's overriding aim is 'not simply to tell the truth but to persuade' (p.7). His epistemic and political standpoint is illuminatingly and enticingly set out in the philosophically rich introductory chapter in which he reflects on how the past, present, and future (or possible futures) are mediated around human interests and values. For those of us that often find academic history a tad dull and parochial, these reflections show how and why history really matters, not just for the sake of faithfully depicting the past, but more importantly, for the sake of realising a humane future.

The substance of the book consists in documenting and then exploring the social and political implications of 'structural changes occurring in the late twentieth and early twenty-first century world economy' (p.10). The principal structural change is

(c) 2020 Springer Nature Limited. 1470-8914 Contemporary Political Theory Vol. 20, S3, S115-S118 
the shift in manufacturing and heavy industrial production from its place of origin in western, specifically European and American, economies, to a new epicentre in eastern and southern economies. We (and this 'we' includes all the world's citizens) now live in a globalised market economy that has all, and more, of the features that Marx and Engels (1969, p. 16) celebrated, and the ones that they deplored, in the nineteenth century capitalist mode of production: 'The need of a constantly expanding market for its products chases the bourgeoisie over the entire surface of the globe. It must nestle everywhere, settle everywhere, establish connexions everywhere', issuing in 'intercourse in every direction, universal interdependence of nations'. One salient consequence of this global extension and intensification of the market economy is the concomitant 'spreading, across the entire human population of the planet, of a more or less uniform understanding of the material "good life" and a desire to share it' (p. 38). These aspirations have to be met, or at least managed, for both political and moral reasons: justice surely requires it.

The major theme of the political circumstances generated by the globalised market economy that Kitching highlights, and on which he ruminates, is the ever increasing redundancy and bankruptcy of the nation state, national politics, and nationalism. If his analysis is on the right track the current intra-national organisation of political responsibilities and allegiances is out of line with economic reality, and what we all, that is, all citizens of the world, need is the creation of a trans-national political order. Without such a trans-national political order and economic regulatory structure the world's citizens' needs and aspirations cannot be met, and this spells danger for the political legitimacy of increasingly emasculated nation states. The trans-national politics that Kitching envisions, as possibility and desideratum, is answerable to the needs of an international economic order, and this consists primarily in the construction and maintenance of a 'trans-national "level playing field" of taxes on wages and profits' (p. 48) along with associated economic regulatory mechanisms. The need for this arises, of course, because of the rapaciously exploitative rules and regulations historically imposed on international trade by the dominant western states.

There are two main reasons why those of us who reside in western liberal democracies should be doing all we can to promote the creation of a trans-national political order and a level playing field for the conduct of economic activities. The first is existential self-interest: a world of such radical economic inequality as currently exists is inherently unstable and dangerous for all. The second reason is the normative one of basic justice: it is simply wrong to live as comfortably as we do when so many millions lack basic life-sustaining necessities. To these two reasons, which make for a powerful combination of motivational force, Kitching adds a noble third. It is the image of a collective interest in a cosmopolitan, universalist, global future in which everyone embraces the Communist Manifesto's resounding principle: 'the free development of each is a prerequisite of the free 
development of all' (quoted p. 111). To take this principle to heart (and mind) on a mass scale will require a new kind of political personality and psychology, one which transcends what Kitching, following Eric Hobsbawm, regards as 'the ungenerous, unimaginative, stultifyingly narrow sensibility that lies at the heart of every nationalism' (p.107). Kitching thinks such political personality and psychology is a possibility; no more than that, but that is enough to make it worth striving for.

What makes Kitching's book distinctive and refreshing is its mix of philosophical, political, and historical reflectiveness trained on sober economic analysis and diagnosis. In a word, it is a fusion of philosophical pragmatism, economic realism, and normative advocacy. It might not be obvious, but the political hopes and desires to which Kitching gives voice are wholly conditioned by a sharp underlying appreciation of Marx's historical materialism. The extent to which this is so is only made explicit in a short but pithy appendix on Marx and Marx's Hegelian heritage. Its guiding thread, which is also the book's Leitmotif, is an aphorism from Marx's famous 'Preface', which avows that '[hu]mankind always sets itself only such problems as it can solve, since, on closer examination, it will always be found that the problem itself only arises when the material conditions necessary for its solution already exist or are at least in the process of formation' (p. 119). Kitching thinks this aphorism is profoundly illuminating and inspiring for the concept of political possibility-as do I, and have done ever since I was alerted to its pregnancy by Kitching's much earlier Karl Marx and the Philosophy of Praxis (1988); it continues to orientate my own writing on ethics, moral progress, and moral revolution. Kitching uses this principle to outline a penetrating historical materialist conception of the practical conditions that enabled and facilitated moral progress with regard to slavery, colonialism, female and racial oppression, and the emergence of the idea of inherent human rights.

The essence of Marx's problem/solution aphorism is that the very fact that a deleterious state of affairs can be identified and articulated clearly as a real human problem that needs to be ameliorated or resolved shows prima facie that the problem is soluble - though not, of course, that it will be solved. As Kitching neatly puts it, 'aspiration is a priori evidence of feasibility' (p. 123); one cannot aspire to something that one believes to be impossible. Consider the proposition that every human will inevitably suffer the ultimate moral harm through their eventual death; despite the grievousness and universality of this harm, it cannot be seen as a moral problem. Now contrast this with the proposition that around a quarter of the world's population suffer severe life-threatening poverty whilst millions of other people enjoy a life of luxury, opportunity, and freedom. This proposition does state a moral problem, because we surely know that the material conditions necessary for its solution do exist. Kitching's book aspires to present the reader with morally and politically desirable real possibilities, not wishfully thought utopian (im)possibilities.

(c) 2020 Springer Nature Limited. 1470-8914 Contemporary Political Theory Vol. 20, S3, S115-S118 S117 
A sceptical reader might still think that the truly human, cosmopolitan, globally instantiated political life that Kitching adumbrates for the near future, and the internationally cooperative structures needed to enable it, is mere wishful thinking. Referring to the Bretton Woods plan for economic recovery towards the end of WWII, Kitching observes that 'in such desperate times radical reform schemes that would normally not get a hearing will be considered and even implemented, albeit partially' (p. 106). We are once again in desperate times across much of the world due to the corona virus pandemic. But if there is one thing that helps mitigate the desperateness of current conditions, it is the palpable awareness that we face these conditions not in national or geographical isolation but together, globally. We know that we are suffering together, and we know that solutions (for which the material preconditions already exist) must, to be effective, be on a global scale and grounded in international coordination and cooperation. Moreover, there are signs for optimism in the quite frequently enunciated desire that a more caring, solidaristic, and egalitarian political community might emerge in the wake of the current crisis. Kitching's appeal for reflection on the nature and conditions of political possibility can only help foster this quest.

\section{References}

Kitching, G. (1988). Karl Marx and the Philosophy of Praxis. London: Routledge.

Marx, K. and F. Engels (1969) Manifesto of the Communist Party. In Marx/Engels Selected Works, Vol. One. Moscow: Progress Publishers.

Publisher's Note Springer Nature remains neutral with regard to jurisdictional claims in published maps and institutional affiliations.

Nigel Pleasants

University of Exeter, Exeter EX4 4RJ, UK

n.j.pleasants@ex.ac.uk 